\title{
HIGH PERFORMANCE THIN LAYER CHROMATOGRAPHIC DETERMINATION OF NIFEDIPINE IN HUMAN SERUM AFTER LIQUID-LIQUID EXTRACTION
}

\author{
Sigrid Mennickent*, Jonathan Contreras, Berta Schulz and Marta de Diego \\ Departamento de Farmacia, Facultad de Farmacia, Universidad de Concepción, P.O. Box 237, Concepción, Chile \\ Mario Vega \\ Departamento de Bromatologia, Nutrición y Dietética, Facultad de Farmacia, Univerdidad de Concepción, P.O. Box 237, \\ Concepción, Chile
}

Recebido em 11/5/11; aceito em 22/8/11; publicado na web em 30/9/11

\begin{abstract}
A method using HPTLC for quantitation of nifedipine in serum was developed and validated. It includes a liquid-liquid extraction, and carbamazepine as internal standard. Chloroform: ethyl acetate: cyclohexane (19:2:2, v/v/v) was the mobile phase. The method showed good relationship $(\mathrm{r}=0.996)(2.00$ to $25.00 \mathrm{ng} / \mathrm{band}$, corresponding to 0.02 and $0.25 \mathrm{ng} / \mu \mathrm{L}$ in serum). The $\%$ RSD of intra-assay and inter-assay, were between 0.57 and 3.56 and 1.16 to 3.60, respectively. LOD and LOQ were 0.72 and $0.86 \mathrm{ng} / \mathrm{band}$, respectively. The recovery values were between 93 and $102 \% . \mathrm{R}_{\mathrm{f}}$ for nifedipine and carbamazepine were 0.31 and 0.10 , respectively.
\end{abstract}

Keywords: nifedipine; high performance thin layer chromatography; quantitative determination.

\section{INTRODUCTION}

Nifedipine is a 1, 4-dyhydropiridine-derivative calcium-channel blocking agent (Figure 1). Nifedipine is used alone or in combination with other classes of antihypertensive agents in the management of hypertension. Calcium-channel blockers, as nifedipine, are considered one of several preferred antihypertensive drugs for the initial management of hypertension in patients with a high risk of developing coronary artery disease, including those with diabetes mellitus. Nifedipine also may be used in the management of hypertension in patients with low-renin hypertension (as black patients), coexisting angina, peripheral vascular-disease, or isolated systolic hypertension, and in geriatric patients.<smiles>COC(=O)C1=C(C)NC(C)=C(C(=O)OC)C1c1ccccc1[N+](=O)[O-]</smiles>

Figure 1. Chemical structure of nifedipine

Other uses of nifedipine are in the management of Prinzmetal variant angina and chronic stable angina pectoris, Raynaud's phenomenom, and preterm labor.

About its pharmacokinetics, approximately of $90 \%$ of an oral dose of nifedipine is rapidly absorbed from the gastrointestinal tract and serum concentrations usually are reached within 0.5-2.0 h, after oral administration as conventional capsules. When the drug is administered as extended-release tablets, its bioavailability relative to conventional nifedipine capsules is about $84-89 \%$. In patients with normal renal and hepatic function, the plasma half-life of nifedipine is about $2 \mathrm{~h}$ when administered as conventional capsules, and about $7 \mathrm{~h}$ when administered

*e-mail: smennick@udec.cl as extended-release tablets. The drug is extensively metabolized in the liver, and $60-80 \%$ of an oral dose of nifedipine is excreted in the urine almost entirely as inactive metabolites. ${ }^{1-3}$ Following administration of a single extended-release tablet under fasting conditions, mean peak plasma nifedipine concentrations of about $115 \mathrm{ng} / \mathrm{mL}$ were reported. ${ }^{2}$

Patient's adherence to antihypertensive drug regimen is a complex but important factor in achieving blood pressure control and reducing adverse cardiovascular outcomes. ${ }^{4-20}$ Non-adherence to antihypertensive medication is about $50 \%$ of patients, ${ }^{4-8,10,12-15,17}$ and only one in three patients have controlled blood pressure. ${ }^{6,9}$ Across the time, it was observed a slow continuous decline in persistence to pharmacotherapy compliance. ${ }^{10,12,13,15}$ Patient's non-adherence to medications has been attributed to both intentional (i.e, a conscious decision not to take medications) and unintentional (i.e, failure to take medications due to poor understanding or forgetfulness) reasons. ${ }^{17}$

The more common ways to evaluate the adherence of the patients with their medication are questionnaires about the daily administration of the drug, and pill counts, with the problem that the results can be true or false..$^{21-27}$ Determination of drug levels in biological fluids can be a useful tool to evaluate pharmacotherapy adherence by relating the serum or plasma levels of drugs with compliance..$^{1-3}$ Patient with hepatic and/or renal damage can be exclude from the study, because these conditions are related with a lower drug excretion and, therefore, with higher plasmatic concentrations.

For determination of nifedipine in blood, some methods using HPLC, ${ }^{28-35}$ voltammetry ${ }^{36-38}$ and spectrophotometry ${ }^{39,40}$ have been reported.

No method was found in the literature for analysis of this drug in blood using HPTLC.

High performance thin layer chromatography (HPTLC) is a technique carried out within a short period of time, as allows for the analysis of a large number of samples simultaneously. Therefore, the principal advantage of HPTLC is a fast analysis, with a high selectivity, accuracy, sensitivity (nanograms in UV absorbance mode and picograms in fluorescence mode) and precision. ${ }^{41}$ Authors have performed some works using HPTLC for quantitative determination of drugs in biological fluids, ${ }^{42-45}$ and in dosage forms, ${ }^{46-51}$ with exact and reliable results.

Therefore, the aim of this study was to develop and validate a fast, sensitive, accurate and precise method using HPTLC for quantitative 
determination of nifedipine in human serum, suitable for medication adherence studies.

\section{EXPERIMENTAL}

\section{Material}

\section{Apparatus}

A Camag (Muttenz, Switzerland) HPTLC system was used, consisting of a TLC Scanner 3, equipped with software winCATS 1.4.2; automatic TLC Sampler 3; vertical twin trough chambers 10 x 10 and $10 \times 20 \mathrm{~cm}$ and HPTLC plates precoated with silica gel $\mathrm{F}$ 254 Merck (Darmstadt, Germany).

Other instrumentations used were WLW Centrifuge (Germany), Heidolph shaker Metrohm (USA), and Reacti-Vap evaporator Thermo Fisher Scientific (Waltham, MA, USA).

\section{Chemicals and reagents}

United States Pharmacopeia (USP) standards of nifedipine and carbamazepine (as internal standard) (Figure 2), with a purity grade of $94 \%$ each, were obtained from Sigma-Aldrich Chemicals (St. Louis, MO). Chloroform, ethyl acetate, cyclohexane and ethanol were obtained from Merck (Darmstadt, Germany). All chemicals and reagents were of analytical grade.

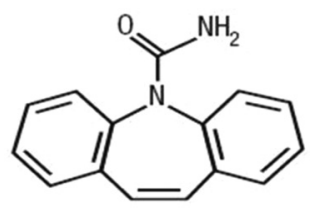

Figure 2. Chemical structure of carbamazepine

\section{Methods}

\section{Standard solutions}

Nifedipine was dissolved with chloroform:ethanol (8:1, v/v), in dark, to obtain a stock solution of $1.00 \mathrm{mg} / \mathrm{mL}$. Later, blank serum samples were spiked with this solution, to obtain final concentrations of 0.02 to $0.25 \mathrm{ng} / \mu \mathrm{L}$ of nifedipine. Working solutions were prepared at concentrations of $0.02,0.05,0.10,0.15,0.20$ and $0.25 \mathrm{ng} / \mu \mathrm{L}$, and quality control samples ${ }^{52}$ were prepared at concentrations of 0.02 0.10 and $0.25 \mathrm{ng} / \mu \mathrm{L}$.

The solutions were protected from light with an aluminum foil wrapping and usually freshly prepared solutions were used.

The internal standard, carbamazepine, was added to serum prior to analysis by pipeting $20 \mu \mathrm{L}$ of a solution of $50 \mathrm{ng} / \mu \mathrm{L}$ into $2 \mathrm{~mL}$ of blank serum.

Drug-free serum used for the validation of the method was obtained from healthy volunteers. Serum collected was stored at $-20^{\circ} \mathrm{C}$.

\section{Serum samples}

Six patient volunteers who were using nifedipine (30-60 mg once daily) as treatment for hypertension participated in this study. The samples were heated at $37^{\circ} \mathrm{C}$ and later centrifuged to obtain serum. The serum samples were frozen at $-20^{\circ} \mathrm{C}$ pending analysis (about 2 days). The sampling was carried out under extremely subdued light and all tubes and syringes were wrapped in aluminum foil because of the photolability of nifedipine.

The volume of serum used was $2 \mathrm{~mL}$. Unknowns were applied as bands 3 times and references were applied as bands 2 times, each, and distribution of bands was done accordingly the data pair method. Standards used were at concentrations of $0.02,0.10$ and $0.25 \mathrm{ng} / \mathrm{uL}$.

\section{Extraction procedure}

For preparation of samples for chromatography, a $20 \mu \mathrm{L}$ aliquot of the internal standard carbamazepine $(50 \mathrm{ng} / \mu \mathrm{L})$ was added to 2 $\mathrm{mL}$ of spiked serum, and vortex-mixed. The sample was then acidified by addition of $100 \mu \mathrm{L}$ of $7 \mathrm{M} \mathrm{HClO}_{4}$, vortex mixed, and later $4 \mathrm{~mL}$ of the extraction solvent mixture dichloromethane: $n$-hexane (30:70, v/v) was added. This mixture was vortex-mixed for $1 \mathrm{~min}$ and then centrifuged for $10 \mathrm{~min}$ at $6000 \mathrm{rpm}$. The organic layer was transferred to another glass tube and the contents were evaporated to dryness at room temperature under a gentle stream of pure nitrogen. The residue was reconstituted in $200 \mu \mathrm{L}$ of chloroform:ethanol (8:2, $\mathrm{v} / \mathrm{v})$. An aliquot of $10 \mu \mathrm{L}$ of this solution was spotted for analysis. All the procedure was accomplished under safety conditions and with the needed precautions because the stability of nifedipine.

\section{Chromatography}

Chromatography was carried out on HPTLC glass backed plates $10 \times 10 \mathrm{~cm}$ and $20 \times 10 \mathrm{~cm}$ precoated with silica gel F 254, layer thickness $0.2 \mathrm{~mm}$ Merck (Darmstadt, Germany), previously washed with methanol and activated at $120^{\circ} \mathrm{C}$ during $20 \mathrm{~min}$.

Sample application was done on $4 \mathrm{~mm}$ bands. The mobile phase consisted of chloroform:ethyl acetate:cyclohexane (19:2:2, v/v/v). The migration distance was $8 \mathrm{~cm}$ and the migration time $12 \mathrm{~min}$. Chromatographic chambers were previously saturated with solvent mixture for $20 \mathrm{~min}$. Densitometry readings were carried out using the Camag system described before, and with a deuterium lamp as the radiation source. Determinations were performed at a wavelength of 238 $\mathrm{nm}$. Figure 3 shows a HPTLC plate with the developed spiked bands.

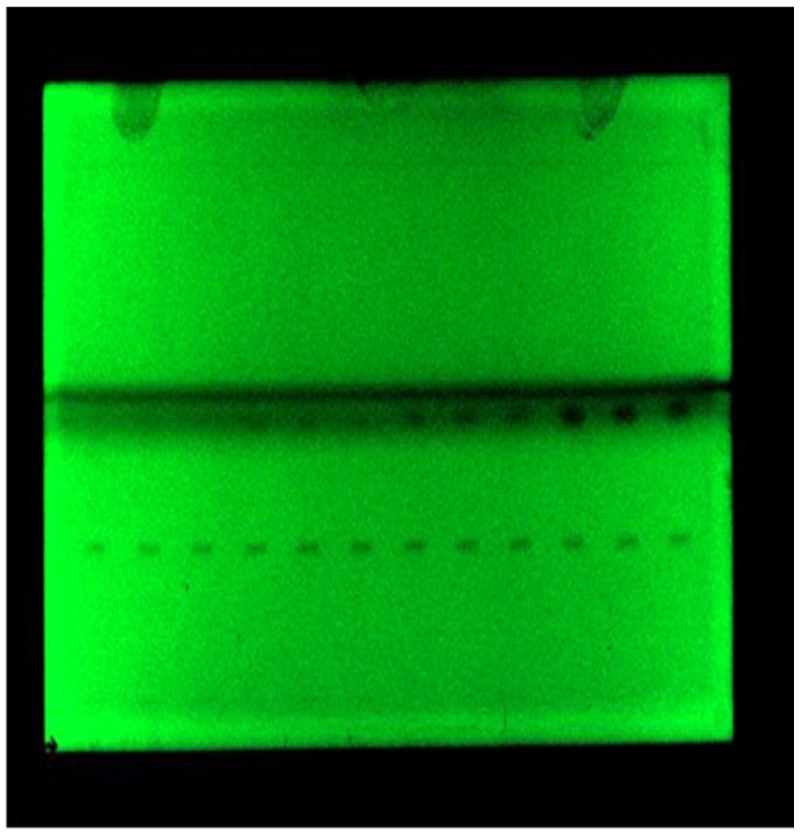

Figure 3. Image of HPTLC plate acquired by the Camag Video Store with 0.02, 0.10, 0.15 and $0.25 \mathrm{ng} / \mu \mathrm{L}$ of nifedipine standard solution. Each solution was applied three times. At the bottom of the plate: applied bands. The developing solvent was run up to $80 \mathrm{~mm}$ in vertical Camag chamber previously saturated with solvent mixture for $20 \mathrm{~min}$

\section{RESULTS AND DISCUSSION}

\section{Method optimization}

The chromatographic conditions were arrived at after investigating several parameters, such as detection wavelength, ideal mobile 
phase and their proportions, internal standards, and optimal conditions for sample extraction.

The best mobile phase was a mixture of chloroform:ethyl acetate:cyclohexane (19:2:2, v/v/v), which provided optimum sensitivity and adequate separation of sharp peaks $\left(\mathrm{R}_{\mathrm{f}}\right.$ for nifedipine ad the internal standard carbamazepine were 0.31 and 0.10 , respectively).

Some wavelengths were tried, and $238 \mathrm{~nm}$ was selected as working wavelength. Complete resolution of the peaks with clear baseline separation was obtained of this way.

\section{Calibration curves}

Calibration curves were constructed using peak-area ratio for the nifedipine and the internal standard carbamazepine as a function of the concentration added. The linear range was between $0.02-0.25 \mathrm{ng} /$ $\mu \mathrm{L}$ which corresponded to 2.00 and $25 \mathrm{ng} /$ band, respectively, after the extraction process and applying $10 \mu \mathrm{L}$ to the chromatographic plates. Each solution was applied as bands 3 times. Solutions of concentration of $0.02,0.05,0.10,0.15,0.20$ and $0.25 \mathrm{ng} / \mathrm{uL}$ were analyzed. This range of solution concentrations include the nifedipine concentration expected in serum $(115 \mathrm{ng} / \mathrm{mL}=0.115 \mathrm{ng} / \mu \mathrm{L}){ }^{2}$ Standard curves were constructed by plotting the peak area ratio of the analyte to the internal standard.

The calibration curves $(n=5)$ of nifedipine were described by: $y$ $=5464.6 \times( \pm 0.1) \times-56.504( \pm 0.1)$ with a correlation coefficient, $r=0.996$.

\section{Precision and accuracy}

Quality control samples spiked at three concentrations (0.020.10 and $0.25 \mathrm{ng} / \mu \mathrm{L}$ ) were used to assess precision and accuracy of the method. Three replicates each were prepared and each replicate was applied as bands three times. Inter-assay precision and inter-assay accuracy were calculated after repeated analysis in three different analytical runs. Each experiment included the sample extraction step.

Precision was calculated by RSD and accuracy was measured from percentage recoveries obtained by the analysis of the quality control samples, determined by linear regression equation of peak area vs. drug concentration.

The accuracy and precision did not exceed $4.25 \%$ of RSD at any level. Precision criteria for an assay method for drugs in biological fluids are that the precision will be 5 to $10 \%$ (RSD). ${ }^{53-55}$

The results are presented in Tables 1 and 2 .

Table 1. Precision of the method

\begin{tabular}{ccc}
\hline $\begin{array}{c}\text { Concentration } \\
(\mathrm{ng} / \mu \mathrm{L})\end{array}$ & \multicolumn{2}{c}{ Relative standard deviation $(\mathrm{RSD}), \%$} \\
\cline { 2 - 3 } & Intra-assay $^{\mathrm{a}}$ & Inter-assay $^{\mathrm{b}}$ \\
\hline 0.02 & 3.56 & 3.60 \\
0.10 & 1.96 & 2.44 \\
0.25 & 0.57 & 1.16 \\
\hline
\end{tabular}

${ }^{a} n=3$; analyzed on the same day (three solutions of each concentration); ${ }^{b} n=9$; analyzed on three different days (three solutions of each concentration prepared for 3 days)

\section{Detection and quantification limits}

Serum spiked with nifedipine standard to obtain concentrations of 0.01-0.02 and $0.05 \mathrm{ng} / \mu \mathrm{L}$ were used to calculate the limit of detection (LOD) and limit of quantification of the method.

LOD was 0.72 and LOQ was $0.86 \mathrm{ng} / \mathrm{band}$, respectively, deter-
Table 2. Method accuracy

\begin{tabular}{cccc}
\hline $\begin{array}{c}\text { Actual } \\
\text { concentration } \\
(\mathrm{ng} / \mu \mathrm{L})\end{array}$ & $\begin{array}{c}\text { Measured } \\
\text { concentration } \\
(\mathrm{ng} / \mu \mathrm{L})^{\mathrm{a}}\end{array}$ & Accuracy, ${ }^{\mathrm{b}}$ & $\begin{array}{c}\text { RSD, } \\
\%\end{array}$ \\
\hline \multicolumn{4}{c}{ Intra-assay $(\mathrm{n}=3)$} \\
\hline 0.020 & $0.047 \pm 0.0017$ & 95.55 & 3.68 \\
0.100 & $0.098 \pm 0.0035$ & 98.90 & 3.56 \\
0.250 & $0.255 \pm 0.0063$ & 102.00 & 2.45 \\
\hline 0.020 & Inter-assay $(\mathrm{n}=9)$ & & 4.20 \\
0.100 & $0.047 \pm 0.0020$ & 93.00 & 4.25 \\
0.250 & $0.098 \pm 0.0042$ & 97.37 & 3.73 \\
\hline
\end{tabular}

${ }^{\mathrm{a}}$ Each value is the mean \pm standard deviation. ${ }^{\mathrm{b}}$ Founded concentration/added concentration $\mathrm{x} 100$. $^{\mathrm{C}}$ Relative standard deviation.

mined using the equations: ${ }^{56} \mathrm{LOD}=3.3 \mathrm{\sigma} / \mathrm{b}$; LOQ $=10 \mathrm{\sigma} / \mathrm{b}$, where $\sigma$ is the standard deviation of the responses, and $\mathrm{b}$ corresponds to the slope obtained from the curve peak area versus concentration of the analyte. These values were experimentally verified.

\section{Selectivity}

The selectivity of the method was examined by preparing and analyzing checked by analyzing human serum samples spiked with nifedipine and the internal standard carbamazepine.

Moreover, three independent blank human serum samples were checked for any interfering peaks. No interference was observed.

Nifedipine and carbamazepine were well separated under the HPTLC conditions applied. Resolution $\left(\mathrm{R}_{\mathrm{S}}\right)$ between both peaks was $3.08\left(R_{\mathrm{f}}\right.$ carbamazepine $=0.10 ; \mathrm{R}_{\mathrm{f}}$ nifedipine $\left.=0.31\right)($ Figure 4$)$.

Table 3 summarized all of validated values.

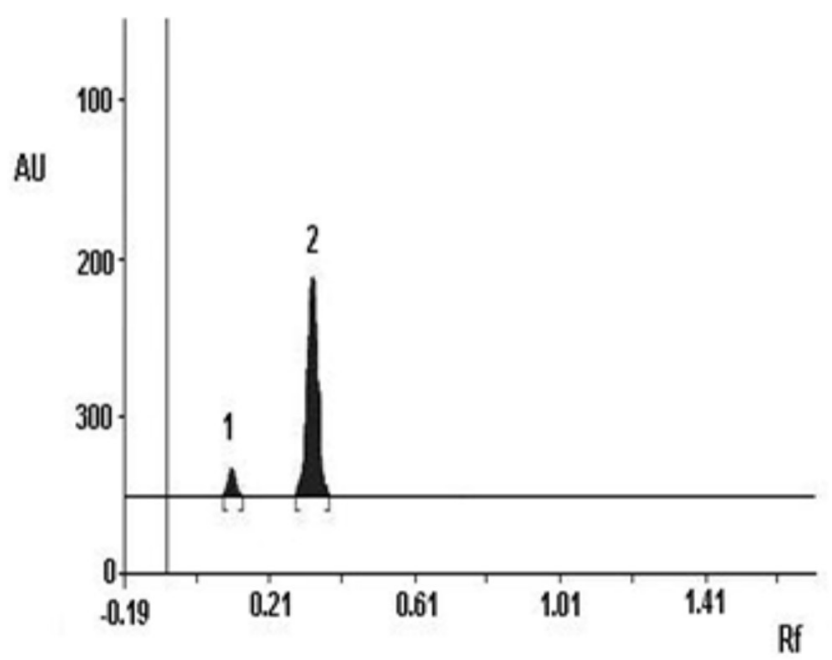

Figure 4. Separation between nifedipine peak and the internal standard carbamazepine peak. $1^{\circ}$ peak: carbamazepine; $2^{\circ}$ peak: nifedipine. Axis X: $R_{f}$ retarding factor. Axis $Y: A U$ : absorbance unit

\section{Application of the method}

The nifedipine concentration ranged between 0.07 and $0.23 \mathrm{ng} /$ $\mu \mathrm{L}$. Nifedipine plasma concentration of $115 \mathrm{ng} / \mathrm{mL}(0.115 \mathrm{ng} / \mu \mathrm{L})$ is described in literature following administration of a single extendedrelease tablet under fasting conditions. ${ }^{2}$ 
Table 3. Results of method validation

\begin{tabular}{ll}
\hline Parameter & Value \\
\hline Linearity & \\
$\quad$ Linear range $(\mathrm{ng} / \mu \mathrm{L})$ & $0.02-0.25$ \\
$\mathrm{R}$ & 0.996 \\
Precision (RSD) & \\
$\quad$ Intra-assay ( $\mathrm{n}=3)$ & $0.57-3.56$ \\
$\quad$ Inter-assay (n=9) & $1.16-3.60$ \\
Accuracy $(\% \mathrm{R})$ & \\
$\quad$ Intra-assay (n=3) & $95.55-102.00$ \\
Inter-assay (n=9) & $93.00-98.85$ \\
LOD (ng/band) & 0.72 \\
LOQ (ng/band) & 0.86 \\
Selectivity $\left(\mathrm{R}_{\mathrm{f}}\right.$ ) & \\
$\quad$ Nifedipine & 0.31 \\
Carbamazepine & 0.10 \\
\hline
\end{tabular}

\section{CONCLUSIONS}

The method was sensitive enough to detect a quantity as low as $0.72 \mathrm{ng} / \mathrm{b}$ and and the linear range was between $0.02-0.25 \mathrm{ng} / \mu \mathrm{L}$ which corresponded to 2.00 and $25 \mathrm{ng} / \mathrm{band}$, respectively, after the extraction process and applying $10 \mu \mathrm{L}$ to the chromatographic plates. This range includes serum concentration found in literature $(0.115$ $\mathrm{ng} / \mu \mathrm{L} \approx 0.11 \mathrm{~g} / \mu \mathrm{L})$. Both accuracy and precision values were very acceptable, and the peaks of nifedipine and of the internal standard carbamazepine were well resolved. Liquid-liquid extraction yields a good recovery of nifedipine from serum.

No other method using HPTLC was found in the literature, for the quantification of nifedipine in human serum neither in human plasma.

The analysis is fast, and the method allows a large number of samples to be measured simultaneously. This method can be reliably applied to drug adherence evaluation.

\section{ACKNOWLEDGMENTS}

The authors would like to thank the Research Council at the University of Concepción (Projects DIUC n ${ }^{\circ}$ 208.074.041-1.0 and no 208.074.040-1.0).

\section{REFERENCES}

1. Mc Evoy, G.; AHFS Drug Information, $51^{\text {th }}$ ed., American Society of Health- System Pharmacists: Bethesda, 2009.

2. Hardman, J.; Limbird, L.; Las Bases Farmacológicas de la Terapéutica, $10^{\text {th }}$ ed., Mc Graw-Hill: México, 2003.

3. Sweetman, S.; Martindale, Guía Completa de Consulta Farmacoterapéutica, 34 ${ }^{\text {th }}$ ed., Pharma Editores S.L.: Barcelona, 2003.

4. Benson, J.; Britten, N.; BMJ 2002, 325.

5. Marentette, M. A.; Gerth, W. C.; Billings, D. K.; Zarnke, K. B.; Can. J. Cardiol. 2002, 18, 649.

6. Krousel-Wood, M.; Thomas, S.; Muntner, P.; Morisky, D.; Current Opinion in Cardiology 2004, 19, 357.

7. Wogen, J.; Krelick, C. A.; Livornese, R. C.; Yokoyama, K.; Frech, F.; J. Manag. Care Pharm. 2004, 10, 88.

8. Degli, E.; Sturani, A.; Di Martino, M.; Falasca, P.; Novi, M. V.; Baio, G.; Buda, S.; Volpe, M.; J. Hum. Hypertens. 2002, 16, 439.
9. Ren, X. S.; Kazis, L. E.; Lee, A.; Zhang, H.; Miller, D.; J. Clin. Phar. Ther. 2002, 27, 47.

10. Conlin, P. R.; Gert, W. C.; Fox, J.; Roehm, J. B.; Bocuzzi , S. J.; Clin. Ther. 2001, 23, 1999.

11. van Wijk, B. L.; Klungel, O. H.; Heerdink, E. R.; de Boer, A.; Pharmacoepidemiol. Drug Saf. 2006, 15, 587.

12. van Wijk, B. L.; Klunge, O. H.; Heerdink, E. R.; de Boer, A.; J. Hypertens. 2005, 23, 2101.

13. Wang, P. S.; Bohn, R. L.; Knight, E.; J. Gen. Intern. Med. 2002, 1, 504.

14. Breekveldt-Postma, N. S.; Penning-van Bees, F. J.; Siiskonen, S. J.; Falvey, H.; Vincze, G.; Klungel, O. H.; Herings, R. M.; Curr. Med. Res. Opin. 2008, 24,121.

15. Bloom, B. S.; Clin. Ther. 1988, 20, 671.

16. Fitz-Simon, N.; Bennett, K.; Feely, J.; Ther. Clin. Risk Manag. 2005, 1, 93.

17. Bokhour, B.; Berlowitz, D.; Long, J.; Kressin, N.; J. Gen. Intern. Med. 2006, 221, 577.

18. Johnell, K.; Rastam, L.; Lithman, T.; Sundquist, J.; Merlo, J.; BMC Public Health 2005, 5, 1471.

19. Kidd, K. E.; Altman, D. G.; Control Clin. Trials 2000, 2,184S.

20. Dolder, C.; Furtek, K.; Lacro, L.; Jeste, D.; Psychosomatics 2005 , 46,135 .

21. Osterberg, L.; Blaschke,T.; Drug Therapy 2005, 353, 487.

22. Cantrell, C. R.; Eaddy, M. T.; Shah, M. B.;Regan, T. S.; Sokol, M. C.; Med. Care 2006, 44, 300.

23. Aikens, J.; Nease, D.; Nau, D.; Klinkman, M.; Schwenk, T.; Ann. Fam. Med. 2005, 3, 23.

24. Jukic, V.; Coll. Antropol. 2003, 27, 119.

25. Mushlin, A. I.; Appel, F. A.; Arch. Intern. Med 1977, 137, 318.

26. Payne, K. A.; Esmonde-White, S.; Curr. Hypertens. Rep. 2000, $2,515$.

27. Choo, P. W.; Rand, C. S.; Inui, T.S .; Med. Care 1999, 37, 846.

28. Tamaki, W.; Hiroyoshi, N.; Hitoshi, N.; Shigeru, O.; Mitsukazu, K.; Japan JTDM 1999, 16, 358.

29. Zaater, M.; Hasan, E.; Najib, N.; Pol. J. Pharmacol. 2000, 52, 307.

30. Gil-Agusti , M. T.; Carda-Broch, S.; Monferrer-Pons, L. I.; EsteveRomero, J. S.; Biomed. Chromatogr. 2005, 20, 154.

31. Aboud-Auda, S. H.; Najjar, T. A.; Al-Khamis, K. I.;Al-Hadiya, B. M.; Ghilzai, N. M.; Al-Fawzan, N. F.; J. Pharm. Biomed. Anal. 2000, 22, 241.

32. Wang, X. D.; Lim, J. L.; Lu, Y.; Chen, X.; Huang, M.; Chowbay, B.; Zhou, S. F.; J. Chromatogr., B: Anal. Technol. Biomed. Life Sci. 2007, $852,534$.

33. Shah, S. A.; Savale, S. S.; Rathod, I. S.; Shishoo, C. J.; Ind. J. Pharm. Sci. 1999, 61, 81 .

34. Kowalczuk, D.; Wawrzycka, M. B.; Maj, A. H.; JAOAC 2006, 89, 71.

35. Guo, Y.; Dai, J.; Qian, G.; Guo, N.; Ma, Z.; Guo, X.; Int. J. Pharmaceutics 2007, 341, 91.

36. Madhusudana, R. T.; Jayarama, R. S.; Anal. Lett. 2004, 37, 2079.

37. Ghoneim, M. M.; Tawfik, A.; Khatashaba, P. Y .; Anal. Bioanal. Chem. 2003, 375, 369 .

38. Ozaltin, N.; Yardimci, C.; Suslu, I .; J. Pharm. Biomed. Anal. 2002, 30, 573.

39. Rahman, N.; Ahmad Khan, A.; Hejaz Azmi, N.; Il Farmaco 2004, 55, 47.

40. Alagar Raja, M.; Selva Kumar, D.; Muthu Kumar, S.; Purnina, T.; Int. J. Res. Pharm. Sci. 2010, 1, 20.

41. Wilson, I.; Ther. Drug Monit. 1996, 18, 484.

42. Mennickent, S.; Sobarzo, A.; Vega, M.; Godoy, C. G.; de Diego, M.; J. Sep. Sci. 2007, 30, 2167.

43. Mennickent, S.; Vega, M.; Godoy, C. G.; J. Chil. Chem. Soc. 2003, 48, 71.

44. Mennickent, S.; Fierro, R.; Vega, M.; de Diego, M.; J. Sep. Sci. 2009, 32,1454 . 
45. Mennickent, S.; Sobarzo, A.; Vega, M.; de Diego, M.; Godoy, C. G.; Rioseco, P.; Saavedra, L.; IJPCP 2010, 14, 41.

46. Mennickent, S.; Vega, M.; Godoy, C. G.; Yates, T.; Bol. Soc. Chil. Quim. 2000, 45, 615 .

47. Mennickent, S.; Yates, T.; Vega, M.; Godoy, C. G.; Saelzer, R.; Rev. Med. Chile 2002, 130, 409.

48. Mennickent, S.; Pino, L.; Vega, M.; Godoy, C. G.; de Diego, M.; J. Sep. Sci. 2007, 30, 772

49. Mennickent, S.; Pino, L.; Vega, M.; de Diego, M.; J. Sep. Sci. 2007, 31, 201.

50. Mennickent, S.; Nail, M.; Vega, M.; de Diego, M.; J. Sep. Sci. 2007, 30, 1893.
51. Mennickent, S.; Contreras, J.; Reyes, C.; Vega, M.; de Diego, M.; J. PLanar Chromatogr. 2010, 23, 75.

52. Food and Drug Administration; Guidance for Industry. Bioanalytical Method Validation, U. S. Department of Health and Human Services, Food and Drug Administration, USA, 2001.

53. Shabir, G.; J. Chromatogr., A 2003, 987, 57.

54. Quattrochi, O.; Abelaira, S.; Laba, R.; Introducción a la HPLC: Aplicación y práctica, $1^{a}$ ed., Artes Gráficas Farro: Buenos Aires, 1992.

55. Daniel, W.; Bioestadística. Base para el Análisis de las Ciencias de la

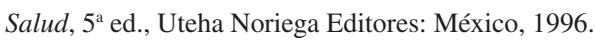

56. The United States Pharmacopeia; U. S. Pharmacopeial Convection Inc., Rockville, 2005. 